\title{
THE ROLE OF FISCAL DOMINANCE ON THE EFFECTIVENESS OF MONETARY POLICY: AN EVALUATION OF 2002-2012 PERIOD IN TURKEY ${ }^{1}$
}

\section{Dr. Meryem FÍLIZ BAŞTÜRK*}

\begin{abstract}
Monetary policy loses its function when the public debt of an economy is high and short-term and a large amount of this debt is foreign currency denominated. In such a case, an increase in shortterm interest rates applied as a tool of tight monetary policy to reduce inflation leads to higher risk premiums and generates capital outflow. Thus, such a policy increases the inflation, causing an unexpected result. In this regard, fiscal dominance can be claimed to play a decisive role in the effective operation of monetary policy.

In Turkey, fiscal dominance reached very high levels especially in the aftermath of the crisis of February 2001. This study analyze monetary policies adopted in Turkey between 2002 and 2012 according to specific periods. Within this framework, this study firstly investigates the period when implicit inflation targeting regime was implemented and fiscal dominance was high. Secondly, it examines the period when explicit inflation targeting regime was adopted, followed by the period when monetary policy took price stability along with financial stability into consideration. This classification will enable to evaluate the impact of fiscal dominance indicators on the implementation of monetary policy in Turkey for the period analyzed.
\end{abstract}

Keywords: Fiscal Dominance, Monetary Policy, Inflation Targeting.

JEL Classification: E52, E58, E63

\footnotetext{
${ }^{1}$ This study is based on author's PhD. thesis and this is the expanded version of a paper presented at EconAnadolu 2013 but not published.

*PhD./Senior Lecturer. Uludag University, Faculty of Economics and Administrative Sciences, Department of Economics (BURSA).
} 


\section{PARA POLITIKASININ ETKINLIĞINDE MALİ BASKINLIĞIN ROLÜ: TÜRKIYYE'DE 2002-2012 DÖNEMİ İÇİN BİR DEĞERLENDİRME}

\section{$\ddot{O} \mathbf{Z}$}

Kamu borcunun yüksek, kısa vadeli ve önemli bir kısmının yabancı para cinsinden olduğu ekonomilerde para politikası işlevselliğini kaybetmektedir. Zira böyle bir durumda enflasyonu düşürmek için uygulanan sıkı bir para politikası uygulaması olarak kısa vadeli faiz oranlarındaki artış, ülkenin risk primini arttırarak sermayenin dışarıya çıkmasına yol açmaktadır. Böylece uygulanan politika enflasyonu arttırarak beklenenin tersi bir sonuç ile karşılaşılmaktadır. Bu doğrultuda para politikasının etkin bir şekilde çalışmasında mali baskınlı̆̆ın belirleyici bir özelliğe sahip olduğu söylenebilir.

Türkiye'de özellikle Şubat 2001 krizinden sonra mali baskınlık çok yüksek seviyelere çıkmıştır. Bu çalışmada Türkiye'de 2002 - 2012 yılları içerisinde uygulanan para politikası kendi içerisinde dönemselleştirilmektedir. Bu çerçevede ilk olarak örtük enflasyon hedeflemesi rejiminin uygulandĭ̆ ve mali baskınlığın yüksek olduğu, ikinci olarak açık enflasyon hedeflemesi rejiminin uygulandiğı, üçüncü olarak da fiyat istikrarı ile birlikte finansal istikrarın da dikkate alındiğı bir para politikasının uygulandı̆̆ dönemselleştirme doğrultusunda inceleme yapılmaktadır. Yapılan bu sinıflandırmayla, Türkiye'de ele alınan dönemde mali baskınlık göstergelerinin para politikasının hareket alanına etkisi değerlendirilmeye çalışılmaktadır.

Anahtar Kelimeler: Mali Baskınlı, Para Politikası, Enflasyon Hedeflemesi,

JEL Sinıflandirmasi: E52, E58, E63

\section{INTRODUCTION}

In the aftermath of the crises of November 2000 and February 2001, Turkey put "Transition to the Strong Economy Program” into effect in May, 2001. Implicit inflation targeting regime was adopted as of early 2002 as the necessary prerequisites were not met. High inflation rates and dollarization and insufficient technical infrastructure were some of the factors which led to introducing this regime, but high degree of fiscal dominance was the primary factor.

In 2006, explicit inflation targeting regime was adopted. Since fiscal dominance decreased then, monetary transmission channels started to operate. The economic gains highly affected the new policy implemented by the central bank following the global financial crisis of 2008. As a matter of fact, inflation rates decreased, fiscal dominance diminished thanks to the tight monetary and fiscal policies 
implemented in the aftermath of the 2001 crisis. As the restructuring process of the banking sector started, banks that used to provide funds to the public sector started to provide loans to the private sector. All these developments brought flexibility in the monetary policy implemented in the aftermath of the crisis.

Presenting a general evaluation of the 2002-2012 period in Turkey, this study shows that the obstacle posed by the fiscal dominance to the monetary policy during the implementation of implicit inflation targeting regime was removed under the explicit inflation targeting regime and the new policy regime implemented following the global financial crisis. The period analyzed in this study clearly shows that fiscal policy had a visible impact on the effective operation of the monetary policy.

\section{IMPLICIT INFLATION TARGETING PERIOD}

In Turkey, implicit inflation targeting was adopted in the 2002-2005 period. According to Özatay (2009: 21-22), implicit inflation targeting regime that refers to a period when an effort is made to meet the conditions required for explicit inflation targeting includes some features of both explicit and implicit inflation targeting. Under this regime, the main objective of the central bank is price stability, which is the same under explicit inflation targeting regime, and it has tool independence to ensure stability. Secondly, the inflation target set by the central bank is announced on the first day of the new-year. Thirdly, short-term interest rates are used as the main policy tool. Fourthly, the central bank gives detailed information on how decisions on interest rates are taken. Fifth, the Council of Ministers and the Parliament's Planning and Budget Commission are informed about the policies implemented twice a year. Finally, the public are constantly informed about the policies in effect. Unlike explicit inflation targeting, interest rates decision are not set by the monetary policy committee. As a result, the public do not know when decisions are taken. Also, a monetary policy report is issued instead of an inflation report.

In the implicit inflation targeting period short-term interest rates were used by the central bank as a policy tool to ensure price stability then (Başçı and Kara, 2011: 11). During this period, the monetary base was used as an additional nominal anchor as required by the program implemented in cooperation with the IMF (TCMB, 2004: 25). The reason why not the explicit inflation targeting regime but the implicit inflation targeting regime was initially adopted is based on some factors.

The first one was very high inflation rates. High inflation rates both posed a problem for transition to explicit inflation targeting and caused individuals to focus on the previous inflation. After the crisis, the inflation rate was $68 \%$ in late 2001. It was hardly in 2004 when inflation in Turkey decreased to single digits (Kara, 2006: 3). The second reason was that the institutional and technical infrastructure necessary for the regime was inssuficient since an inflation targeting regime was not adopted in Turkey in the previous years. The restructuring process of the banking system was 
continuing in the aftermath of the crisis, which posed a problem as well. The third reason was high dollarization, which was also put forward by Akıncı, Barlas Özer and Usta (2005). In their study, they stated that asset dollarization increased beyond the high levels of the 1990s as a result of the crises of 2000 and 2001 and then decreased as of 2002. A different study by Sever (2012) emphasized that dollarization started to have a downward trend after 2001. In both studies, decreasing dollarization was attributed to the implementation of the stability program. The fourth and the main reason was that high fiscal dominance was an obstacle to the effective implementation of the monetary policy (Özatay, 2009: 18-19; Kara and Orak, 2008: 37-41).

\subsection{The Decisive Effect of Fiscal Dominance}

Fiscal dominance is defined as the restrictive effect of high public debt on the effectiveness of monetary policy. High public debt, its being short-term and mostly foreign-currency denominated increased the risk premium, thereby weakening the effectiveness of monetary policy (Özatay, 2009: 19). This effect of public debt on monetary policy was first analyzed by Saregnt and Wallace (1981), and it was stated that a reduction in the growth rate of money increases inflation since the main financing source for budget is seignorage revenue. In other words, when there is fiscal dominance, monetary policy is no longer an appropriate policy for decreasing inflation (Favero - Giavazzi, 2004: 3-4).

Under normal macro-economic circumstances in which fiscal dominance is not high, tight monetary policy decreases inflation through two channels. Firstly, the increase in policy interest rates affects other interest rates and leads to a decrease in the aggregate demand and inflation. Secondly, high interest rates bring about an appreciation in domestic currency and cause inflation to decrease. In developing countries that adopt inflation targeting, tight monetary policies introduced when fiscal dominance $^{2}$ is high cause the prices to increase rather than decrease, leading to a "price puzzle". It results from the fact that when the public debt of a country is high and mainly short-term and most of this debt is foreign currency denominated, it increases the risk premium of the country and causes capital outflow (Blanchard, 2004: 3-5).

Although "price puzzle" is due to misidentification of VAR models in the literature, it is a structural feature of developing countries with high fiscal dominance (Aktaş, Kaya and Özlale, 2010: 124). In such a case, exchange rate puzzle is also observed since currency depreciation rather than currency appreciation occurs as a result of the tight monetary policy; conventional uncovered interest rate parity condition does not work as expected, and risk premium channel becomes more decisive (Aktaş, Kaya and Özlale, 2005: 9).

\footnotetext{
${ }^{2}$ Fiscal policy affects monetary policy in various aspects (Zoli, 2005: 1). However, this study does not include these aspects since it focuses on the restrictive effects of fiscal policy on monetary policy when fiscal dominance is high under inflation targeting regime.
} 
In the period when implicit inflation targeting was adopted in Turkey, central bank did not have an influence on long term yield curve because of the risk premium resulting from high and short term public debt ${ }^{3}$. High risk premium also caused volatility in exchange rates and led to high exchange rate pass-through (Kara, 2006: 5). Studies on exchange rate pass-through in Turkey analyzed this issue in two periods: before and after 2001. In fact, transition to floating exchange rate regime in the aftermath of the crisis of February 2001 was the reason for this categorization. Basing their studies on this categorization, Kara and Öğünç (2005; 2008), Kara, et al. (2005), Volkan, Saatçioğlu and Korap (2007) argued that exchange rate pass-through decreased and diminished following the transition to floating exchange rate regime. In one of their studies analyzing a different period (2002-2011), Kara and Öğüç (2012) emphasized that the exchange rate pass-through decreased then. The period they focused on in their study covers the period after transition to floating exchange rate. In their previous study, they analyzed the period presenting a comparison of fixed exchange rate and floating exchange rate.

The indicators of fiscal dominance that restrict monetary policy under implicit inflation targeting regime are presented in Table 1. Budget Deficit / GDP, general government debt stock / GDP, public sector borrowing requirement / GDP, public net debt stock / GDP, which are commonly used in the literature, were used as fiscal dominance indicators in this study.

Table 1. Fiscal Dominance Indicators

\begin{tabular}{|l|c|l|l|l|}
\hline Year & $\begin{array}{l}\text { Budget Deficit } \\
\text { /GDP(\%) }\end{array}$ & $\begin{array}{l}\text { General Sector } \\
\text { Government Debt } \\
\text { Stock (EU Defined, } \\
\text { \% of GDP) }\end{array}$ & $\begin{array}{l}\text { Public } \\
\text { Borrowing } \\
\text { Requirement/GDP(\%) }\end{array}$ & $\begin{array}{l}\text { Public } \\
\text { Debt } \\
\text { Stock/GDP(\%) }\end{array}$ \\
\hline $\mathbf{2 0 0 2}$ & 11.47 & 74.0 & 9.98 & 61.5 \\
\hline $\mathbf{2 0 0 3}$ & 8.84 & 67.7 & 7.32 & 55.2 \\
\hline $\mathbf{2 0 0 4}$ & 5.21 & 59.6 & 3.63 & 49.1 \\
\hline $\mathbf{2 0 0 5}$ & 1.06 & 52.7 & -0.07 & 41.7 \\
\hline
\end{tabular}

Ministry of Finance, Undersecretariat of Treasury

When fiscal dominance indicators in the table above are closely examined, it is seen that fiscal dominance kept its importance in the period from the crisis to 2005 (Ersel and Özatay, 2008: 45). In this period, budget deficit / GDP ratio was high despite showing a downward trend except for 2005 and was higher than the Maastricht Criteria ${ }^{4}$. The ratio of general government debt stock to GDP was also higher than the Maastricht Criteria in 2002 and 2003. Public Net Debt Stock / GDP ratio

\footnotetext{
${ }^{3}$ The countries cannot borrow long-term loans with fixed interest rates in their domestic currency. This position called original sin in the literature (Gürcihan and Y1lmaz, 2007: 5).

${ }^{4}$ According to the Maastricht Criteria, budget deficits should not be over 3 percent of GDP; government debtto-GDP ratios should not exceed 60 percent of GDP.
} 
gradually decreased from $61.5 \%$ in 2002 to $41.6 \%$ in 2005 . The table also clearly shows that there was a downward trend in the public sector borrowing requirement during the same period.

Under the implicit inflation targeting regime, policy interest rates were not raised at all. The main reason was that an increase in policy interest rates would increase the risk premium of the country, causing doubts about the sustainability of the debt (Birkan, 2010: 27). In other words, using short-term interest rates as a policy tool under fiscal dominance means "leaning against the wind", as stated by Kara (2006: 9-10). Alper and Hatipoğlu (2009: 12) associated decreasing inflation rates during this period with capital inflows rather than the monetary policies implemented.

\subsection{Literature Review}

In the literature, there are several studies indicating how fiscal dominance restricts the functionality of monetary policy under inflation targeting regime. In his study (2004), Blanchard argued that fiscal policy was more effective than monetary policy to decrease the inflation in Brazil in 2002-2003 period since public debt was high then and most of this debt was foreign currency denominated. In other words, monetary policy was not effective because fiscal dominance was high. Favero and Giavazzi (2004: 14) also analyzed the same period and reached similar conclusions. They argued that the increase in interest rates, increased the country's risk premium and caused capital outflow and exchange rate depreciation during this period marked with a bad economic equilibrium. In her study, Zoli (2005) analyzed how fiscal policy affected monetary policy in developing countries. She also examined whether fiscal dominance constricted monetary policy in Brazil for the 2002-2004 period. The study argued that there was a bad economic equilibrium due to the high public debt resulting from the economic crisis and the uncertainty about the election's outcome during the period analyzed. The study also emphasized that exchange rates reacted to the implementation of a tight monetary policy in a way contrary to expectations since fiscal dominance was a decisive factor in country spreads and exchange rates. In other studies on Brazil has apprehend same result as Blanchard, (2004), Favero and Giavazzi (2004) claimed that fiscal policy was a more appropriate tool than monetary policy to equilibrate the economy. Abdel and Youssef (2011) studied whether fiscal dominance in Egypt affected the target of price stability set by the central bank. The central bank committed to implementing inflation targeting regime by 2005 as soon as the necessary conditions were met. This study emphasized that fiscal policy had a significant effect on monetary policy.

\subsubsection{Studies on Turkey}

The period covered in the studies specifically analyzing the effect of fiscal dominance on monetary policy under inflation targeting regime in Brazil is of high importance since this period has features similar to the conditions in Turkey during the implicit inflation targeting period. That is why particularly these studies were reviewed. In their study on Turkey, Aktaş, et al. (2010) analyzed the 
role of fiscal dominance in the effectiveness of monetary policy for the 1999-2006 period. Their study examined whether tight monetary policy was shaped by the fiscal conditions of the country. That is why they preferred to include July 2001 period when fiscal discipline was not achieved despite the implementation of tight monetary policy and September 2003 period when tight monetary policy was implemented along with fiscal discipline. For the first period, it was stated that the debt level and risk premium as well increased due to the increase in the short term interest rates. The study also showed that domestic currency depreciated; inflation which was expected to decrease thanks to the policy implemented increased to the contrary; a "price puzzle" was clearly observed in impulse-response functions. For the second period, the study showed that when public debt/GDP ratio started to decrease, the risk premium also decreased; domestic currency appreciated, and most importantly inflation decreased, thereby enabling the "price puzzle" to disappear. The authors emphasized that there was a bad equilibrium in the economy during the first period while it turned into a good equilibrium during the second period, which was attributed to the removal of restrictive effect on the monetary policy as fiscal discipline was partially achieved. Barışı (2010) analyzed the impact of fiscal dominance on the banking sector in Turkey for the 1989-2007 period. In this study, various fiscal dominance indicators were used, which are budget deficit/GDP, current account deficit/GDP, public debt stock/GDP, and domestic debt stock/M2Y. Bank assets, loans used by the private sector, total loans, investment securities, deposits in TL, foreign exchange deposit accounts, equity capital, and profit-loss indicators were used as indicators of the banking sector. In this study, real exchange rates and real interest rates were used as endogenous variables. Since a relation between real exchange and real interest rates used as endogenous variables and current account deficit used as an indicator of fiscal dominance was not observed, they were left out of the analysis. There was not a significant relation between fiscal dominance indicators and equity capital, foreign exchange deposit accounts and assets that are related to the banking sector. It was stated that an increase in public debt stock that is one of the fiscal dominance indicators decreases loans granted to the private sector, total loans and deposits. In addition, deposits decrease when domestic debt stock increases. The study also concluded that an increase in budget deficit decreases investment securities; an increase in public debt stock increases investment securities; an increase in domestic debt stock results in a decline in banks' profits. Granger causality test was used in this study. According to the results of the Granger causality test, real interest rates have a bigger impact on banking variables when compared to the real exchange rates, and among fiscal dominance indicators, public debt stock is the one that has the biggest effect on banking sector. In their study, Arabacı and Filiz Baştürk (2013) analyzed the effectiveness of the interest rate channel for the 2001-2008 period. In this study, a price paradox was observed in the 20012004 period, which was attributed by the authors to high fiscal dominance in this period, but the price paradox disappeared in the 2004-2008 period, and interest rate channel started to work more effectively. 
It is also important to mention studies analyzing the success of inflation targeting regime in Turkey. As a matter of fact, the success of the regime shows that monetary policy works effectively. Ermişoğlu (2013) compared the period before (1995-2005) and after (2006-2012) the adoption of the inflation targeting regime in Turkey in terms of inflation performance. In this study, the period before the inflation targeting regime was divided into two sub-periods: 1995-2001 and 2002-2005. This study found out that the period when inflation targeting was in effect, both inflation level and volatility and inflation persistence decreased. It was also stated that the confidence in monetary policy increased during this period, and economic actors started to consider inflation targets while making inflation expectations. Based on these findings, it was concluded that the inflation targeting regime implemented in Turkey was successful in the period analyzed in this study.

In their study, Güney and Ceylan (2014) examined the performance of inflation targeting in Turkey for the 1990-2012 period. They analyzed whether the effect of monetary policy on inflation and production changed inflation targeting regime or not. The period analyzed was divided into three periods. The first one covered the years between 1990 and 2001, and it was stated that inflation responded to monetary policy shock by showing an upward trend. For the 2002-2005 period, the response of the inflation to monetary policy shock was statistically insignificant while in the 20062012 period, inflation responded by first decreasing and then increasing, but the result was statistically found to be insignificant. Also, there was no finding showing that monetary policy had an adverse effect on growth during the period when inflation targeting regime was adopted. In conclusion, according to the authors, the reason why inflation did not respond to the monetary policy shock with an increase during the inflation targeting period was that economic actors considered the targeted inflation rates rather than the past inflation rates while making inflation expectations.

\section{EXPLICIT INFLATION TARGETING PERIOD}

Fiscal dominance started to decrease as a result of the tight monetary and fiscal policies and structural reforms introduced with the "Transition to the Strong Economy Program". In Turkey, fiscal dominance posed the biggest obstacle to monetary policy particularly during 2001-2005 period. Fiscal discipline plays an important role in shaping inflation expectations under fiscal dominance since the Central Bank of the Republic of Turkey (CBRT) frequently emphasized the importance of fiscal discipline in achieving low inflation rates, ensuring economic stability and shaping expectations during this period (Kara, 2006: 11).

Monetary policy works effectively as long as it is supported by tight fiscal policy. In this respect, fiscal discipline affects inflation targeting regime through four channales. Firstly, it increases confidence in the policy implemented by reducing the risk premium through expectations. Secondly, the prices of goods produced and services rendered by the public sector have a decisive role on 
inflation and to achieve the target of price stability it is highly important that prices increase within the framework of fiscal discipline rules. Thirdly, it affects inflation through wage rises determined in line with the income policy because these wage rises shape inflation expectations. Finally, fiscal discipline affects inflation targeting regime through direct procurement of goods and services by the public sector (TCMB, 2005: 10-11).

In line with the developments observed in the economy, Turkey made a transition to explicit inflation targeting in 2006. Inflation targeting is set in collaboration with the government and Consumer Price Index is used while setting inflation targeting as it is clear and easy for the public to understand and follow. While setting the target, uncertainty band was determined as two points and a point target was preferred. With transition to explicit inflation targeting, Turkey agreed to set threeyear targets and committed to publicizing the underlying reasons if the targets were not achieved (Kartal, 2011: 87-88). During this period, IMF's conditionality changed as net international reserves carried out the function of performance criteria and inflation revision criteria were used instead of Monetary Base performance criteria and net domestic asset indication target (TCMB, 2005: 1-11).

According to Alper and Hatipoğlu (2009: 12-18), the reasons why inflation rates were at low levels under explicit inflation targeting regime were transition to flexible exchange rate regime in the aftermath of the crisis of 2001 and the central bank's gaining its independence with the amendments to the relevant law made in April, 2001 and the general economic performance to implement structural reforms. However, in May-June 2006 period international capital flows turned out to the advantage of developed countries and energy prices were very high then, which are thought to have caused the central bank not to achieve the inflation target (Uygur, 2010: 40-41).

In a study by Özatay (2008), a comparison of three periods of fiscal consolidation (1994-95, 2000, 2003-2005) was presented. It was stated in the study that for the 2003-2005 period, when implicit inflation targeting regime was implemented in Turkey, the ratio of public debt to national income and interest expenditures decreased. The study also showed that inflation and interest rates started to decrease in response to the economic growth, and confidence in economy increased. When the table below is analyzed, we see that total public net debt stock / GDP ratio continued to decrease during the period of explicit inflation targeting. Also, the ratio of general government debt stock to GDP was lower than the Maastricht Criteria. The ratio of budget deficit to GDP remained below the level set by the Maastricht Criteria.

Table 2. Fiscal Dominance Indicators

\begin{tabular}{|l|l|l|l|l|l|}
\hline Year & $\begin{array}{l}\text { Budget Deficit } \\
\text { /GDP(\%) }\end{array}$ & $\begin{array}{l}\text { General Sector } \\
\text { Government Debt } \\
\text { Stock (EU Defined, } \\
\text { \% of GDP) }\end{array}$ & $\begin{array}{l}\text { Public } \\
\text { Borrowing } \\
\text { Requirement/GDP(\%) }\end{array}$ & $\begin{array}{l}\text { Debt } \\
\text { Stock/GDP(\%) }\end{array}$ \\
\hline
\end{tabular}




\begin{tabular}{|l|l|l|l|l|}
\hline $\mathbf{2 0 0 6}$ & 0.61 & 46.5 & -1.83 & 34.0 \\
\hline $\mathbf{2 0 0 7}$ & 1.63 & 39.9 & 0.08 & 29.5 \\
\hline $\mathbf{2 0 0 8}$ & 1.83 & 40.0 & 1.62 & 28.2 \\
\hline
\end{tabular}

Ministry of Finance, Undersecretariat of Treasury

The central bank increased the policy interest rates for the first time in June 2006 since it started to implement inflation targeting regime ${ }^{5}$. The effect of an increase of 175 base points in policy interest rates was observed in the second half of 2007 and aggregate demand and inflation decreased, confirming that the monetary transmission mechanism was working. Decreasing fiscal dominance especially affected the effective operation of the mechanism (Kara and Orak, 2008: 54-55). Increasing energy and food prices that continued as of 2006 were the main reason for high inflation rates. Tight monetary policy introduced because of high inflation rates were implemented until September, 2007, and policy interest rates were reduced by 225 basis points in September 2007-February 2008 when the circumstances started to return to normal. As of March, interest rate cut was given up, but it was stated that interest rates could be increased in April if necessary (TCMB, 2008a: 2). Short-term interest rates were increased by 150 basis points in May-July period but were not changed in AugustOctober period (TCMB, 2008b: 2-3).

\section{THE MONETARY POLICY IMPLEMENTED IN THE AFTERMATH OF THE GLOBAL CRISIS}

In the aftermath of the global crisis, the Central Bank changed its policy and adopted a "fast and front-end strategy". In line with this strategy, the Central Bank reduced its policy interest rates in November, 2008 by 1025 base points $^{6}$. The reason why the Central Bank made a change in its policy is thought to have resulted from the worries about a probable current account deficit and macroeconomic inequilibrium as short-term capital inflows into developing countries like Turkey increased because of the policies implemented by the developed countries in the aftermath of the crisis. However, the policy "a single tool for a single target" dominant before the crisis was no longer sufficient after the crisis. The global crisis showed that it was important to take financial stability into account. Since it was not possible to attain the targets by using a single tool, different policies were

\footnotetext{
${ }^{5}$ During the period of implicit inflation targeting regime, policy interest rates were never increased. An increase in policy rates would cause doubts about the sustainability of the debt as it would increase the risk premium of the country. That is why it was not preferred (Birkan, 2010: 27).

${ }^{6}$ In his study (2010: 43), Uygur stated that the central bank was relatively late to respond to the crisis when compared to other countries. In their study, Başçı and Kara (2011: 10) emphasized that among other developing countries Turkey was the first country to cut interest rates and reduced the rates most. In their study analyzing the role of monetary policy during the crisis period in Turkey, Alp and Elekdağ (2011: 17-22) stated that floating exchange rate regime and inflation targeting limited the effects of the global financial crisis on Turkey. In their study, they said that if the central bank did not reduce the interest rates, the growth would be -6.2 and if the fixed foreign exchange regime was adopted, the growth would reach -8.0. Based on these results, they underlined that the policy implemented by the central bank in the crisis period was appropriate.
} 
also adopted. In fact, the interest rate tool could not simultaneously ensure price stability and financial stability (Başçı and Kara, 2011: 10-11). Within the framework of the new monetary policy introduced by the central bank in November, 2010 to overcome this problem, required reserve ratios and expansion of the interest rate corridor started to be used as policy tools. The purpose of introducing required reserve ratios was to arrange credit expansion while the interest rate corridor aimed at limiting the short term capital inflows by causing uncertainty about interest rates. All in all, the new monetary policy strategy is composed of two main targets, two intermediate targets, and there are three tools to achieve these targets (Özatay, 2011: 30).

Table 3. Policy Tools and Targets of Turkish Central Bank in the aftermath of the Crisis

\begin{tabular}{|l|c|c|}
\hline \multicolumn{1}{|c|}{ Tools } & Main Target & Intermediate Target \\
\hline Policy Interest Rate & Price Stability & \\
\hline Interest Rate Corridor & Financial Stability & to limit short-term capital \\
& & inflows \\
\hline Required Reserve Ratio & & $\begin{array}{c}\text { to slow down credit } \\
\text { expansion }\end{array}$ \\
\hline
\end{tabular}

Kara, 2012: 15

According to the classification of Kara (2012), it is possible to analyze the monetary policies adopted as of November, 2010 in three periods. During the first period of November 2010 - August 2011, capital inflows into Turkey increased as developed countries reduced their policy interest rates almost to zero and implemented quantitative easing. Inflation was below the target then, which gave policy makers some room for manoeuvre, decreased interest rate corridor and increased required reserve ratios. Interest rate corridor was used to constrain short term capital movements while required reserve ratios were used to limit loan supply. During the period of August 2011 - October 2011, central bank narrowed the interest rate corridor to constrain a sudden increase in the capital movements in an environment of uncertainty resulting from the emergence of public debt problem as some countries in the Eurozone. During the period of October 2011 - December 2012, inflation showed an upward trend more than expected. As a result, the central bank adopted a tighter monetary policy (Kara, 2012: 26-27).

Fiscal dominance in Turkey reached very high levels in the aftermath of the crises of November 2000 and February 2001, causing the monetary policy to lose its function. Some countries in the Eurozone underwent the same experience in the aftermath of the global financial crisis of 2008, specifically in 2010 because public debts of some countries increased after the crisis and some uncertainties started to emerge about how to sustain these debts. However, the strong structure of the 
banking system and lower degrees of fiscal dominance prevented Turkey from undergoing the same experience in the aftermath of 2008 crisis (Yörükoğlu and Kılınç, 2012: 339-342). The table below shows the fiscal dominance indicators for the years between 2009 and 2012 in Turkey. It is seen that the ratio of general government debt stock to GDP was below the level set by the Maastricht Criteria and showed a downward trend year by year. The table also shows that the ratio of budget deficit to GDP was below the Maastricht Criteria except for 2009 and 2010.

Table 4. Fiscal Dominance Indicators

\begin{tabular}{|l|c|l|l|l|}
\hline Year & $\begin{array}{l}\text { Budget Deficit } \\
\text { /GDP(\%) }\end{array}$ & $\begin{array}{l}\text { General Sector } \\
\text { Government Debt } \\
\text { Stock (EU Defined, } \\
\text { \% of GDP) }\end{array}$ & $\begin{array}{l}\text { Public } \\
\text { Borrowing } \\
\text { Requirement/GDP(\%) }\end{array}$ & $\begin{array}{l}\text { Public } \\
\text { Debt } \\
\text { Stock/GDP(\%) }\end{array}$ \\
\hline $\mathbf{2 0 0 9}$ & 5.54 & 46.0 & 5.05 & 32.5 \\
\hline $\mathbf{2 0 1 0}$ & 3.67 & 42.3 & 2.36 & 28.9 \\
\hline $\mathbf{2 0 1 1}$ & 1.37 & 39.1 & 0.14 & 22.3 \\
\hline $\mathbf{2 0 1 2}$ & 2.08 & 36.2 & 0.99 & 17 \\
\hline
\end{tabular}

Ministry of Finance, Undersecretariat of Treasury

The graph below shows public debt figures in years. Public debt decreased from 74.0 percent in 2002 to 40.0 percent in 2008 . The decreasing public debt gave the central bank some room for manoeuvre in its policies when the global financial crisis broke out. Public debt reached high levels between 2002 and 2004, in particular, restricting the effectiveness of the monetary policy. During this period, public debt was also above the level set by the Maastricht Criteria. In the following years, it continued to show a downward trend though it increased in 2009 and 2010. 
Figure 1. General Government Debt Stock (EU Defined \% of GDP)

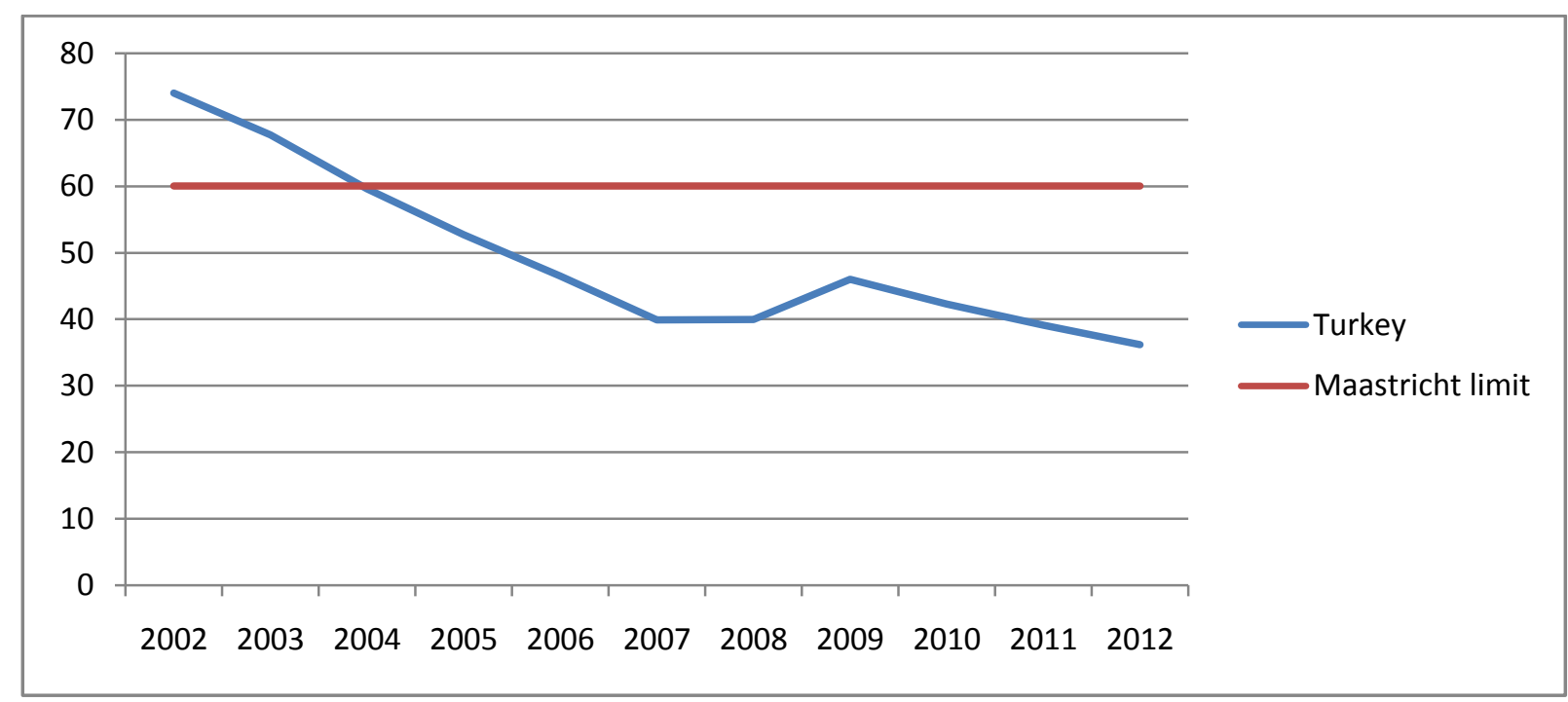

Source: Undersecretariat of Treasury

\section{CONCLUSION}

Under inflation targeting regime, fiscal dominance has a major role in enabling monetary policy to function effectively. In Turkey, floating exchange rate regime was introduced in the aftermath of the crisis of February 2001 and the "Transition to the Strong Economy Program" was implemented in May. The restructuring process started for the banking sector that was about to collapse after the crises of November 2000 and February 2001. This process caused the pubic debt to reach high levels in the aftermath of the crises. When the public debt of a country is both short-term and high and a great amount of this debt is foreign currency denominated, an increase in short-term interest rates used as a tight monetary policy to reduce inflation rates increases the risk premium of the country, causes capital outflow and domestic currency depreciation. Also, the policy adopted to decrease inflation rates end up with an increase in the general level of prices. In such a case, a "price puzzle" and an "exchange rate puzzle" are observed in the economy.

This was the case in Turkey in the aftermath of the crisis of February 2001. In fact, an implicit inflation targeting regime was adopted in Turkey due to high fiscal dominance, high inflation and high dollarization as well as the strong effects of exchange rate pass-through. During this period, monetary policy was enhanced by tight fiscal policy, and fiscal dominance started to decrease. Also, inflation rates were lower than the projected levels and an economic growth was observed. In line with these developments, Turkey introduced an explicit inflation targeting regime in 2006. Under the explicit inflation targeting regime, international capital movements turned out to the advantage of developed countries and food and energy prices increased, which led the country not to achieve its inflation targets. However, fiscal dominance did not cause an obstacle to the monetary policy. The central bank increased the inflation rates in June 2006. This decreased the aggregate demand and inflation, showing that the monetary transmission mechanism was working as expected. 
In 2008, when the impacts of the global financial crisis became visible, the central bank made a policy change in November 2010 in addition reducing the interest rates rapidly and in advance. The new monetary policy was shaped taking not only the price stability but also the financial stability into consideration. Accordingly, required reserve ratios and interest rate corridor as well as short term interest rates were adopted as policy tools. As stated by Yörükoğlu and K1lıç (2012), a strong fiscal equilibrium provided a wide operational framework in the central bank's policy against the crises.

\section{REFERENCES}

Abdel, H. and Ghaffar, Y. (2011) "Fiscal Dominance an Obstacle to Inflation Targeting in Egypt", Money in the Middle East and North Africa, (eds.David Cobham - Ghassan Dibeh), Routledge,Oxon, 218-237.

Akıncı, Ö., Barlas, Özer, Y. and Usta, B. (2005) "Dolarizasyon Endeksleri Türkiye'deki Dolarizasyon Sürecine İlişkin Göstergeler”, Türkiye Cumhuriyet Merkez Bankası, Çalışma Tebliği, No.05/17: 1-23.

Aktaş, Z., Kaya, N. and Özlale, Ü. (2010) "Coordination between Monetary Policy and Fiscal Policy for an Inflation Targeting Emerging Market", Journal of International Money and Finance, 29(2010): 123-138.

Aktaş, Z., Kaya, N. and Özlale, Ü. (2005) "The Price Puzzle in Emerging Markets: Evidence from the Turkish Economy Using "Model Based" Risk Premium Derived from Domestic Fundamentals", The Central Bank of the Republic of Turkey Research Department Working Paper, 05/02: 1-28.

Alp H. and Elekdağ, S. (2011) "The Role of Monetary Policy in Turkey during the Global Financial Crisis", IMF Working Paper, WP/11/150. http://www.imf.org/external/pubs/ft/wp/2011/wp11150.pdf 10.10.2011.

Alper, E. and Hatipoğlu, O. (2009) "The Conduct of Monetary Policy in Turkey in the Pre and Post crisis Period of 2001 in Comparative Perspective: a Case for Central Bank Independence", MPRA Paper No. 18426: 1-33, http://mpra.ub.uni-muenchen.de/18426/, (04.06.2010).

Arabacı, Ö. and Filiz, Baştürk, M. (2013) "Faiz Oranı Kanalının 2001-2008 Döneminde Türkiye'de Etkinliğinin Değerlendirilmesi”, Anadolu Üniversitesi Sosyal Bilimler Dergisi, 13(2): 15-34.

Barışık, S. (2010) “Türkiye'de Finansal Serbestleşme Sürecinde Mali Baskınlığın Bankacılık Sektörüne Etkisi (1989 - 2007 Dönemi Ekonometrik Analiz)”, Zeitschrift für die Welt der Türken Journal of World of Turks, 2(1): 429-447.

Başçı, E. and Kara, H. (2011) "Finansal İstikrar ve Para Politikası", İktisat İşletme ve Finans, 26(302): 9-25. 
Birkan, Özden A. (2010) “An Indicator of Monetary Conditions for Turkey”, Ekonomik Yaklaşım, 21(74): 23-38.

Blanchard, O. (2004) "Fiscal Dominance and Inflation Targeting: Lessons From Brezil", NBER Working Paper 10389, Cambridge, http://www.nber.org/papers/w10389, (16.10.2010).

Ermiş̧oğlu, E. (2013) “Türkiye'de Enflasyon Hedeflemesi: Bir Başarı Hikayesi Mi?”, BDDK Bankacılık ve Finansal Piyasalar, 7(1): 31-58.

Ersel, H. and Özatay, F. (2008) "Fiscal Dominance and Inflation Targeting: Lessons from Turkey" Emerging Markets Finance\&Trade, 44(6): 38-51.

Favero, C. and Giavazzi, F. (2004) "Inflation Tareting and Debt: Lessons from Brazil", NBER Working Paper 10390, Cambridge, http://www.nber.org/papers/w10390, (15.12.2010).

Güney, P. and Ceylan, İ. (2014) “Enflasyon Hedeflemesi ve Türkiye Deneyimi”, H.Ü. İktisadi ve İdari Bilimler Fakültesi Dergisi, 32(1): 143-164.

Gürcihan, B. and Yılmaz, E. (2007) "Türkiye'de Kamu Borç Stokunun Yapısı: Orijinal Günah Göstergeleri ve Risk-Dahil Kamu Borç Yükü”, Türkiye Cumhuriyet Merkez Bankası, Çalışma Tebliği, No.07/02: 1-22.

Kara, H. (2012) “Küresel Kriz Sonrası Para Politikası”, İktisat İşletme ve Finans, 27(315): 9-36.

Kara, H. (2006) "Turkish Experience with Implicit Inflation Targeting", Research and Monetary Policy Department Working Paper, No: 06/03, The Central Bank of the Republic of Turkey.

Kara, H. and Orak, M. (2008) "Enflasyon Hedeflemesi”, Ekonomik Tartışmalar Konferans1,10.10.2008-İstanbul, http://www.tcmb.gov.tr/yeni/iletisimgm/enfhed kara orak.pdf, (18.08.2010).

Kara, H., Küçük Tuğer, H., Özlale, Ü., Tuğer, B., Yavuz, D. and Yücel, E. (2005) "Exchange Rate Pass-Through in Turkey: Has it Changed and to What Extend?", The Central Bank of the Republic of Turkey, Research Department Working Paper, No: 05/04: 1-52.

Kara, H. and Öğünç, F. (2012) “Döviz Kuru ve İthalat Fiyatlarının Yurtiçi Fiyatlara Etkisi”, İktisat İşletme ve Finans, 27(317): 9-28.

Kara, H. and Öğünç, F. (2008), "Inflation Targeting and Exchange Rate Pass-Through: The Turkish Experience”, Emerging Markets Finance \& Trade, 44(6): 52-66.

Kara, H. and Öğünç, F. (2005) "Exchange Rate Pass-Throuhg in Turkey: It is Slow but is it Really Low?", Research Department Working Paper, No: 05/10, The Central Bank of the Republic of Turkey. 
Kartal, F. (2011) “Türkiye'de Enflasyon Hedeflemesi Stratejisi ve Para Politikasının Görünümü”, Maliye Finans Yazıları, 25(91): 77-100.

Özatay, F. (2011) “Merkez Bankası'nın Yeni Para Politikası: İki Hedef-Üç Ara Hedef-Üç Araç”, İktisat İşletme ve Finans, 26(302): 27-43.

Özatay, F. (2009) "Enflasyon ve Para Politikası”, Türkiye Ekonomisi: Yeni Yapı (2000-2008), (eds. N.Özkaramete Coşkun), Ankara: İmaj Kitabevi, 1-34.

Özatay, F. (2008) "Expansionary Fiscal Consolidations: New Evidence from Turkey, Economic Research Forum", Working Paper Series, Woeking Paper No: 406, http://www.erf.org.eg/CMS/uploads/pdf/1212043038_406.pdf (03.04.2010).

Sargent Thomas, J. and Wallace, N. (1981), "Some Unpleasant Monetarist Arithmetic", Federal Reserve Bank of Minneapolis Quarterly Review, 5(3), pp.1-17.

Sever, E. (2012) “Türkiye'de Dolarizasyon Süreci ve Döviz Kuru Belirsizliği İlişkisi”, SosyoEkonomi, Ocak-Haziran 2012-1:204-222.

TCMB (2005) "Enflasyon Hedeflemesi Rejiminin Genel Çerçevesi ve 2006 Yılında Para ve Kur Politikası", www.tcmb.gov.tr/yeni/duyuru/2005/DUY2005-56.php, (02.03.2010).

TCMB (2004), Para Politikası Raporu: 2004-I.

TCMB (2008a), Enflasyon Raporu: 2008-II.

TCMB (2008b), Enflasyon Raporu: 2008-IV.

Uygur, E. (2010) "The Global Crisis and the Turkish Economy", TWN Global Economy Series, Financal Crisis and Asian Developing Countries, No.21: 1-66.

Volkan, A., Saatçioğlu, C. and Korap, L. (2007) "Impact of Exchange Rate Changes on Domestic Inflation: The Turkish Experience", Discussion Paper 2007/6, Turkish Economic Association, http://www.tek.org.tr/dosyalar/VOLKAN-SAATCI-KORAP.pdf , (09.10.2010).

Yörükoğlu, M. and Kılınç, M. (2012) "Globalisation of the interaction between fiscal and monetary policy” BIS Policy Papers, No.67, Bank for International Settlements. http://www.bis.org/list/bispapers/index.htm, (01.02.2013).

Zoli, E. (2005) "How does Fiscal Policy Affect Monetary Policy in Emerging Market Countries?", BIS Working Papers, No:174. Bank for International Settlements. http://www.bis.org/publ/work174.htm, (01.02.2013). 